\title{
Short Communication: Species diversity of mangrove in Kutai National Park, East Kalimantan, Indonesia
}

\author{
ERNY POEDJIRAHAJOE ${ }^{1, \vartheta}$, IIN SUMBADA SULITYORINI ${ }^{2}$, LIRIS LIS KOMARA ${ }^{2, v}$ \\ ${ }^{1}$ Department of Forest Resource Conservation, Faculty of Forestry, Universitas Gajah Mada. Jl. Agro, No 1, Bulaksumur, Sleman 55281, Yogyakarta, \\ Indonesia. Tel.: +62-274- 512102, Fax.: +62-274- 550541, `email: ernyrahajoe@ yahoo.com. \\ ${ }^{2}$ Department of Forestry, Sekolah Tinggi Pertanian Kutai Timur. Jl. Sukarno-Hatta No. 1, Sangatta, East Kutai 75387, East Kalimantan, Indonesia. \\ Tel.: +62-549-2031985, •`email: liskomara@ yahoo.co.id
}

Manuscript received: 31 March 2019. Revision accepted: 22 November 2019.

\begin{abstract}
Poedjirahajoe E, Sulityorini IS, Komara LL. 2019. Short Communication: Species diversity of mangrove in Kutai National Park, East Kalimantan, Indonesia. Biodiversitas 20: 3641-3646. Kutai National Park (KNP) in East Kalimantan, Indonesia is blessed with natural mangrove forests. However, there is only very little information relating to the species composition and mangrove diversity. Therefore, this study was conducted to assess the mangrove tree species diversity and richness in Kutai National Park, East Kalimantan, Indonesia. The study results showed that the mangrove trees density was 1,214 trees/ha in the line transect vegetation survey with 1.7 ha plot. The number of mangrove species in KNP was 17 from 6 families. The dominant species with large numbers of individuals were Rhizophora mucronata, Rhizophora apiculata, and Bruguiera sexangula. The diversity index was low in mangroves in Pandan Bay Estuary, and Kaba Bay compared to that in Lombok bay's mangroves.
\end{abstract}

Keywords: Conservation, diversity, floristic, mangrove

\section{INTRODUCTION}

Understanding the mangrove forests structure is very important for ecology and this information is useful for conservation and sustainable management (Suwignyo et al., 2015). The word of mangrove comes from the ancient Malay language, namely mangi-mangi which is used to explain the Avicennia clan and is still used today in eastern Indonesia (Noor et al. 2006). Mangroves are a typical littoral plant formation on the shores of protected tropical and subtropical shores. There are 65 mangroves reported throughout the world (Kathiresan and Bingham 2001). In general, mangroves are grouped into three categories, i.e., true mangroves, followed mangroves, and associated mangroves (Wan Juliana et al. 2010). Mangrove forests are spread in 123 countries with total areas of 15.2 million ha (FAO 2007).

Southeast Asian mangroves are the most developed and have the highest number of species in the world (Giesen \& Wulffraat 1998). Southeast Asia contains the largest global mangrove forests proportion (33.8\%) (Thomas et al. 2017). The largest mangrove areas in Southeast Asia are found in Indonesia (almost $60 \%$ of total Southeast Asia), and there are 268 plant species recorded in Southeast Asian mangrove vegetation, consisting of 129 trees and shrubs, 50 terrestrial plants, 28 epiphytic plants, 24 ferns, 7 palms and 1 pandanus (Giesen et al. 2006). Indonesia has the largest mangrove in the world, reaching $25 \%$ or about 4.25 million ha (Primack, et al. 1998). The mangrove area in East Kalimantan is around 367 thousand hectares (Noor et al. 2006). The mangrove forest area in Kutai National Park
(KNP) was 5,271.4 ha or about $1.44 \%$ of the total mangrove area of East Kalimantan (Gunawan and Sayektiningsih 2014), but has decreased recently to $4,766.3$ ha or about $2.5 \%$ less than the previous area. The forest area decreases lead to the decreasing level of mangrove diversity and the integrity of the mangrove forest area.

Mangrove ecosystems provide the life necessities for coastal communities and support the fishery resources (Kathiresan and Bingham 2001; Garcia et al. 2014), provide a variety of commercial products and ecological services (Saenger 1999). Mangroves are really productive ecosystems and globally important for the coastal environment productivity (Rao and Rao 2017). Mangroves also play an important role in absorbing carbon dioxide and storing carbon in biomass (Widyastuti et al. 2018). Mangroves in Southeast Asia provide ecosystem services that are valuable to human well-being (Brander et al. 2012). Anthropogenic disturbances to mangrove forests in Southeast Asia are relatively extensive. The disturbances are due to aquaculture/ agricultural practices during 19962010 periods (Thomas et al. 2017). KNP mangrove forests continue to experience pressure due to an increase in human activities for settlement, agriculture, and other activities (Bismark and Iskandar 2002; Sayektiningsih and Gunawan 2012).

$\mathrm{KNP}$ is recognized as one of the Indonesia national parks that are designed to preserve Borneo tropical forest ecosystems including mangrove ecosystems that have high productivity (Budiarsa and Rizal 2014). The mangrove forests reduction is almost $23 \%$ of KNP's mangrove forest area (Wijaya 2011). The mangrove forest areas in KNP is 
threatened increasingly because of the widespread of land encroachment and the enclave problems. In 2004, mangrove species found in KNP consisted of Avicennia alba, Ceriops tagal, Casuarina equisetifolia, Sonneratia caseolaris, Avicennia marina, and Lumnitzera racemosa (Rahmadani et al. 2004). Other studies showed that the mangrove in KNP consisted of 13 species, i.e., Rhizophora apiculata, Rhizophora stylosa, Rhizophora mucronata, Bruguiera gymnorrhiza, Bruguiera parvifolia, Bruguiera sexangula, Bruguiera cylindrica, Sonneratia alba, Sonneratia caseolaris, Avicennia alba, Avicennia marina, Ceriops tagal and Xylocarpus granatum (Gunawan and Sayektiningsih 2012; Budiarsa and Rizal 2013). Ecological research has already been done many times, but the information about diversity, evenness, and similarity is rarely found. The objective of this study was to explore information about mangrove tree species diversity and richness in KNP, East Kalimantan.

\section{MATERIALS AND METHODS}

\section{Study area}

This study was carried out in the Kutai National Park coastal areas, namely in mangrove forests of Lombok Bay, Kaba Bay and Pandan Bay estuary in East Kutai Regency, East Kalimantan, Indonesia. The area of mangrove forest as observation object is 1,442.2 ha in Lombok Bay, 1,120.8 ha in Kaba Bay, and 835.4 ha in Pandan Bay estuary. The location of the study area is $117^{\circ} 33^{\prime} 35.873^{\prime \prime E L ~-~}$ $0^{\circ} 26^{\prime} 24.737^{\prime \prime N L}$ and $117^{\circ} 29^{\prime} 58,92 " \mathrm{EL}-0^{\circ} 11^{\prime} 13,153 " \mathrm{NL}$. This study was carried out 5 months approximately from January to May 2018 with a few stages, i.e., preparation, initial processing, field surveys, advanced processing, and reporting.

The study area climate is the equatorial type with annual rainfall of 1 to $1,500 \mathrm{~mm}$. The dry season occurs from December to February and the long rainy season from March to November. The soil is dominated by clay sand (Loam sandy) and is an Alluvial soil group that is poor in clay and a brownish fraction. In the study area, there are several settlements scattered in two sub-districts, i.e., Pandan Bay and North Sangatta (Figure 1). The ethnic groups are quite diverse, i.e., the Kutai, Dayak, Bugis, Banjar and other immigrant tribes. The settlers occupy several villages within 0.5 to $4 \mathrm{~km}$ distance from the mangrove forests. Approximately $40 \%$ of the settlers were reported extracting mangrove forests as their part-time work.

\section{Procedures}

Each of the three study sites consisted of 6 stations with 170 plots. There were 72 plots in Lombok Bay, 56 plots in Kaba Bay and 42 plots in Pandan Bay estuary. The total plot area of the three locations is 1.7 hectares with $0.05 \%$ sampling intensity. According to the Minister of Forestry Regulation Number P.67/Menhut-II/2006 concerning the criteria and standard of forest inventory, $0.01 \%$ sampling intensity for mangroves is sufficient .

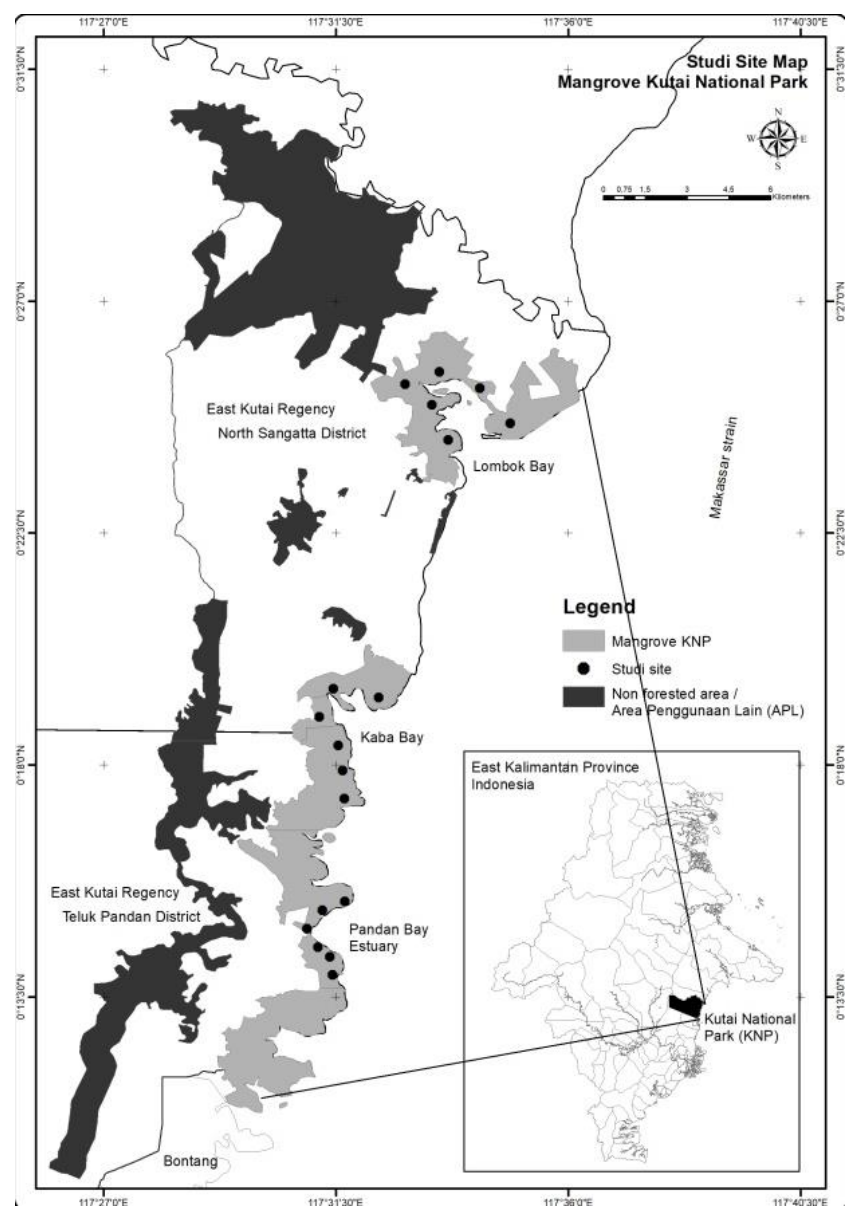

Figure 1. Study location of mangrove area in Kutai National Park, East Kalimantan, Indonesia

Purposive sampling was used in this study with the plot placement adjusted to the field conditions, which can extend according to the edge of the sea or extend along the river line from the seafront to the land. The plot size was 10 $\mathrm{x} 10 \mathrm{~m}$ and the tree diameter measured was $\geq 10 \mathrm{~cm}$. Each plot location was recorded using GPS. The diameters at breast height $(\mathrm{DBH})$ and species of trees in the plots were recorded using the latest botanical classification.

\section{Data analysis}

The data analysis was done using descriptive and quantitative method, to calculate the mangrove species diversity, evenness, and similarity. Species diversity index was calculated using the equation of Shannon Index (Magurran 1988).

$$
\mathrm{H}^{\mathrm{s}}=-\sum\left[\frac{\mathrm{ni}}{\mathrm{N}}\right] \log \left[\frac{\mathrm{ni}}{\mathrm{N}}\right]
$$

Where:

$\mathrm{H}=$ Shannon diversity index

$\mathrm{Ni}=$ Number of individuals per species

$\mathrm{N}=$ Number of individuals of all species 
The Shannon index takes into account the evenness in species abundance. The evenness index was calculated using this equation:

$$
E=\frac{H^{\prime}}{H_{\text {maks }}}=\frac{H^{\prime}}{\operatorname{Ln} s}
$$

$\mathrm{H}_{\max }$ is the logarithm of the total species number. If the evenness value close to zero, there is a large difference in the number of individuals among species. In this study, Simpson index $(D)$ has been considered to determine the evenness distribution. The Simpson index was defined as follows.

$$
D=\sum\left(\frac{n i[n i-1]}{N[N-1]}\right)
$$

Where: $n i$ is the number of individuals in the species and $N$ equals the individual total number. If the diversity increases, the Simpson index declines. We used the complement of Simpson index, i.e., D '= 1 - D.

The similarities of species composition between sites were measured using similarity indexes, i.e., Sorensen coefficient $(K)$ and Jaccard coefficient $(S)$.

$$
\begin{aligned}
& S(\%)=\frac{(a \times 100)}{(a+b+c)} \\
& K(\%)=\frac{(2 a \times 100)}{(2 a+b+c)}
\end{aligned}
$$

Where:

$\mathrm{S}=$ Community similarity index (Jaccard)

$\mathrm{K}=$ Community similarity index (Sorensen)

a $=$ Number of species in the first mangrove forest

$\mathrm{b}=$ Number of species in the second mangrove forest

$\mathrm{c}=$ Number of species found in both mangrove forests

The Sorensen coefficient is completely comparable to the Jaccard coefficient; if the species similarity calculated by the Jaccard coefficient is high, then it will also be high if we use the coefficient the Sorensen coefficient (Ifo et al. 2016). The greater the community similarity index (S) value, the more uniform is the species composition of the two communities.

\section{RESULTS AND DISCUSSION}

\section{Species composition and abundance}

The mangrove community of Kutai National Park (KNP) in general consisted of 17 plant species from 6 families, i.e., Rhizophora mucronata, Rhizophora apiculata, Rhizophora stylosa, Bruguiera sexangula, Ceriops decandra, Ceriop tagal, Sonneratia alba, Sonneratia caseolaris, Avicennia alba, Xylocarpus granatum, Nypa fruticans, Pandanus tectorius (Budiarsa and Rizal 2013). The mangrove species composition in other places with similar geographical conditions is also similar. In the Mahakam delta, the mangrove forest had several zones, i.e., Sonneratia alba-Avicennia sp zone, Rhizophora sp. Zone, and transition zone (Bruguiera, Xylocarpus, Avicennia, and Nypa) and Nypa fruticans zone (Zain et al. 2014). In Bulungan, the northern part of Kalimantan, 10 mangrove species were found, dominated by the family Rhizophoraceae (Kartika et al. 2018). In the southeastern Philippines mangrove forests, 10 of the six families were found (Cañizares and Seronay 2016). The same species were Rhizophora mucronata, Rhizophora stylosa, Rhizophora apiculata, Bruguiera gymnorrhiza, and Bruguiera sexangula.

The mangrove forests of Kutai National Park (KNP) have an important role in the environment and society. Mangroves can provide natural resources such as fish, shrimp, and crabs, and protect coastlines from abrasion. The image data processing in 2016 showed that the KNP mangrove forest area is 4,446.6 ha and occupies approximately $23.3 \mathrm{~km}$-long coastal area. The mangrove area is divided into two main parts. The first is Lombok Bay with 1,442.2 ha large area. The second one is Kaba Bay and Pandan Bay estuary, whose mangroves stretch about 2,952.8 ha. This study has found 17 species of mangrove trees from 6 families. The family Rhizopharaceae had the highest species, i.e., 6 species, followed by Combretaceae 4 species, and other families (Table 1).

The species of Rhizopharaceae family dominated with a total individual number of 1,022. Rhizophora mucronata had the highest number of individuals, i.e., 348, followed by Bruguiera sexangula, 258, and Rhizophora apiculata, 247. Pandanus tectorius, Rhizophora stylosa, and Ceriops decandra were the most rarely found. The average density of mangrove trees was 939 trees/ha in Lombok Bay, 993 trees/ha in Kaba Bay and 1,052 trees/ha in Pandan Bay Estuary (Figure 2).

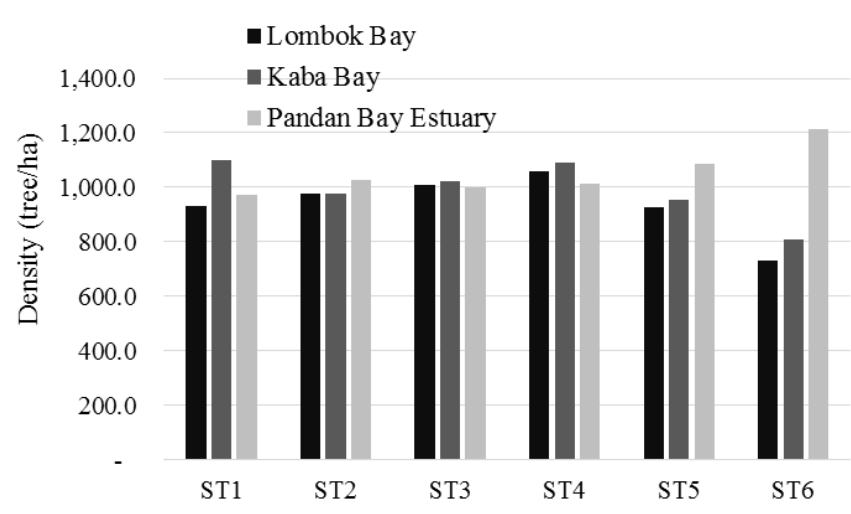

Figure 2. The density of mangrove tree in every station (ST) at three study location in Kutai National Park, East Kalimantan, Indonesia 
Table 1. List of mangrove tree species recorded in Kutai National Park, Indonesia

\begin{tabular}{|c|c|c|c|c|}
\hline Family & Scientific name & Location & Number of species & Number of trees \\
\hline \multirow[t]{3}{*}{ Avicenniaceae } & Avicennia alba Blume. & $\mathrm{LB}, \mathrm{KB}, \mathrm{KPE}$ & \multirow{3}{*}{3} & \multirow{3}{*}{68} \\
\hline & Avicennia lanata (Ridley). & $\mathrm{LB}, \mathrm{KB}$ & & \\
\hline & Avicennia marina (Forssk.) Vierh. & $\mathrm{KB}, \mathrm{PBE}$ & & \\
\hline \multirow[t]{4}{*}{ Combretaceae } & Ceriops decandra Griff. Ding Hou & $\mathrm{KB}$, & \multirow{4}{*}{4} & \multirow{4}{*}{203} \\
\hline & Ceriops tagal (Perr.) C.B.Rob. & $\mathrm{LB}, \mathrm{KB}$ & & \\
\hline & Lumnitzera littorea (Jack) Voigt. & PBE & & \\
\hline & Lumnitzera racemosa Willd. & $\mathrm{KB}, \mathrm{PBE}$ & & \\
\hline Meliaceae & Xylocarpus granatum Koen. & $\mathrm{KB}, \mathrm{PBE}$ & 1 & 24 \\
\hline Pandanaceae & Pandanus tectorius Parkinson ex. Z. & $\mathrm{LB}, \mathrm{KB}, \mathrm{PBE}$ & 1 & 2 \\
\hline \multirow[t]{6}{*}{ Rhizopharaceae } & Bruguiera cylindrica (L.) Bl. & $\mathrm{LB}, \mathrm{KB}, \mathrm{PBE}$ & \multirow{6}{*}{6} & \multirow{6}{*}{1,022} \\
\hline & Bruguiera gymnorrhiza (L.) Lamk. & LB & & \\
\hline & Bruguiera sexangula (Lour.) Poir. & $\mathrm{LB}, \mathrm{KB}, \mathrm{PBE}$ & & \\
\hline & Rhizophora apiculata Blume & $\mathrm{LB}, \mathrm{KB}, \mathrm{PBE}$ & & \\
\hline & Rhizophora mucronata Lamk. & $\mathrm{LB}, \mathrm{KB}, \mathrm{PBE}$ & & \\
\hline & Rhizophora stylosa Griff. & $\mathrm{LB}, \mathrm{KB}, \mathrm{PBE}$ & & \\
\hline \multirow[t]{3}{*}{ Sonneratiaceae } & Sonneratia alba J.E. Smith. & $\mathrm{LB}, \mathrm{KB}, \mathrm{PBE}$ & \multirow{3}{*}{$\begin{array}{c}2 \\
17\end{array}$} & \multirow{2}{*}{316} \\
\hline & Sonneratia caseolaris (L.) Engl. & $\mathrm{LB}, \mathrm{KB}, \mathrm{PBE}$ & & \\
\hline & Total & & & 1,635 \\
\hline
\end{tabular}

Note: LB: Lombok Bay; KB: Kaba Bay; PBE: Pandan Bay Estuary

Table 2. List of biodiversity indexes in three study locations in Kutai National Park, East Kalimantan, Indonesia

\begin{tabular}{lccccc}
\hline Study site & Plots & $\begin{array}{c}\text { Total } \\
\text { individuals }\end{array}$ & $\begin{array}{c}\text { Shannon } \\
\text { diversity } \\
\text { index }(\boldsymbol{H})\end{array}$ & $\begin{array}{c}\text { Evenness } \\
\text { index (E) }\end{array}$ & D \\
\hline Lombok Bay & ST1 & 112 & 2.07 & 0.44 & 0.14 \\
& ST2 & 117 & 2.12 & 0.45 & 0.13 \\
& ST3 & 121 & 2.12 & 0.44 & 0.13 \\
& ST4 & 127 & 2.19 & 0.45 & 0.13 \\
& ST5 & 111 & 2.30 & 0.49 & 0.10 \\
Kaba Bay & ST6 & 88 & 1.89 & 0.42 & 0.17 \\
& ST1 & 99 & 2.06 & 0.45 & 0.15 \\
& ST2 & 88 & 2.21 & 0.49 & 0.14 \\
& ST3 & 92 & 1.82 & 0.40 & 0.21 \\
& ST4 & 98 & 1.96 & 0.43 & 0.18 \\
Pandann Bay & ST5 & 86 & 1.96 & 0.44 & 0.17 \\
Estuary & ST6 & 73 & 1.85 & 0.43 & 0.17 \\
& ST1 & 68 & 1.96 & 0.46 & 0.15 \\
& ST2 & 72 & 1.99 & 0.46 & 0.15 \\
& ST3 & 70 & 1.82 & 0.43 & 0.17 \\
& ST4 & 71 & 1.89 & 0.44 & 0.15 \\
& ST5 & 76 & 1.81 & 0.42 & 0.20 \\
& ST6 & 85 & 2.11 & 0.47 & 0.15 \\
\hline
\end{tabular}

The highest tree density was found in Pandan Bay estuary at station 6 with a density of 1,214 trees/ha, and the lowest one was found in Teluk Lombok, i.e., 733 trees/ha. In 2013, tree density of KNP was high indeed, i.e., 1,033 trees/ha (Budiarsa and Rizal 2013). The mangrove trees density in KNP of East Kalimantan was relatively high compared to other mangroves, maybe because the location was good for mangroves species to grow. The density of mangrove trees was 340 trees/ha in Bulungan, North Kalimantan (Kartika, et al. 2018), 700 trees/ha in Sebuku, South Kalimantan (Ghufrona et al. 2015), 149 trees/ha in Cilacap, Central Java, (Hidayat et al. 2010), and 529 trees/ha in Sarawak, Malaysia (Shah et al. 2016).

\section{Diversity and evenness index}

The Shannon diversity index, Evenness Index and Simpson Index have revealed interesting information.ST 5 in Lombok Bay had high diversity index and medium evenness index, while ST 5 in the Pandan Bay Estuary had the lowest diversity index and low evenness index (Table 2).

The Evenness and Simpson indexes are generally inversely proportional; if the Evenness Index is high then the Simpson Index is low. ST2 in Kaba Bay and ST5 in Lombok Bay had the same evenness index, i.e., 0.49 and both respectively had 0.14 and 0.10 Simpson index. These show that the abundance of species spread moderately evenly in the study area with the chance of finding two individuals of the same species in the plot was $14 \%$ for the first site and $10 \%$ for the latter. Low species abundance in the Lombok Bay was found in the ST6 plot, and in the Pandan Bay estuary was in ST3 and ST5. The low diversity and evenness occurred because of the small number of individuals found. The characteristics of mangrove forests in the three locations are slightly different. Lombok Bay is more accessible than the other locations. Pandan Bay estuary mangrove is difficult to reach. The aquaculture/ponds are spread larger behind mangroves in the Lombok Bay and Kaba Bay area. Although Lombok Bay mangroves have the potential for human disturbance, they still have high species diversity because they have a larger area and a thick forest. Besides, according to Gunawan and Sayektiningsih (2014), restoration and planting activities had been carried out in Lombok Bay, which increased the individuals number or the species number in this area.

\section{Species similarity index}

Similarity coefficient values varied from $36.4 \%$ to $41.9 \%$ for the Jaccard index and $53.3 \%$ to $59.1 \%$ for the Sorensen index (Figure 3). 


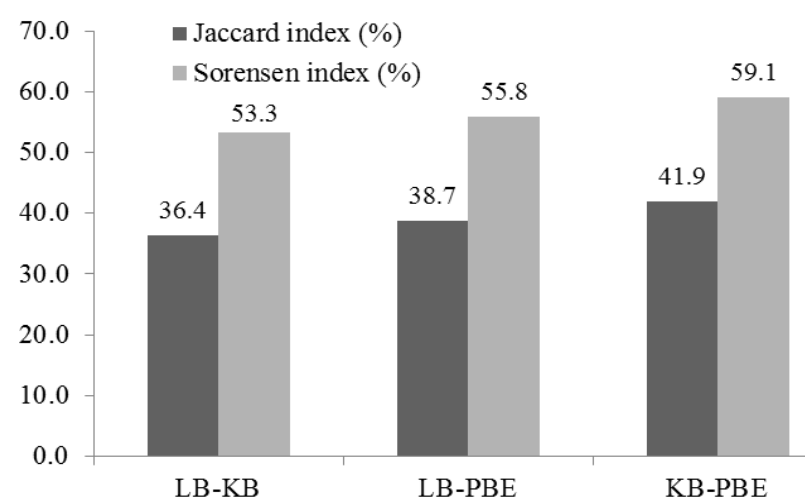

Figure 4. Similarity index between two types of forest in Kutai National Park, East Kalimantan, Indonesia. LB: Lombok Bay, KB: Kaba Bay, PBE: Pandan Bay Estuary

The diversity of species in Lombok Bay was higher than that in Kaba Bay, and the diversity in Kaba Bay was higher than that in Pandan Bay estuary. The Shannon diversity index value obtained in this study was higher than that of other mangrove forests studied in Indonesia.

The forest structural heterogeneity and their high species richness are often interpreted in forest dynamics and succession. There are several factors that can explain the variation of species diversity in this study, i.e., edaphic factors, accessibility (related to human disruption or intervention to the mangrove forests), and successional stages.

In this study, we have studied the differences in species composition among the three sites of mangrove forests through the similarity indexes of Jaccard and Sorensen. These indexes provide a very good idea about the species presence or absence in the transect plot inventory. The species composition similarity between those two survey locations (LB-KB, LB-PBE, and KB-PBE) was low in Jaccard index and moderate in Sorensen index. This means that species composition similarities between those two survey sites were rather low. In the assessment, a low forest diversity status can inform that the mangrove forests have been degraded. Although the two locations, i.e., Kaba Bay and Pandan Bay estuary are difficult to access, but mangrove degradation can occur due to various human activities.

In conclusion, the number of mangrove species varied greatly among sites with the number of individuals reaching above 1,500 individuals and the density reaching 1,000 trees ha. The mangroves in Kutai National Park have high diversity, with moderate evenness index.

\section{ACKNOWLEDGEMENTS}

The author would like to thank the Kutai National Park management unit for supporting and giving the opportunity for the author to carry out this research. The author also thanked the lecturers and students of Sekolah Tinggi Pertanian Kutai Timur in Sangatta, Indonesia who were very helpful in the field survey.

\section{REFERENCES}

Bismark M, Iskandar S. 2002. Study of the proboscis monkey (Nasalis larvatus) total population and social structure in Kutai National Park, East Kalimantan. For Res Bull 631: 17-29.

Brander LM, Wagtendonk AJ, Hussain SS, McVittie A, Verburg PH, de Groot RS, van der Ploeg S. 2012. Ecosystem service values for mangroves in Southeast Asia: A meta-analysis and value transfer application. Ecosyst Serv 1: 62-69.

Budiarsa AA, Rizal S. 2013. Mapping and analysis of the damage level to mangrove forests in Kutai National Park Based on Landsat ETM Satellite image data and vegetation density. J Trop Fish Sci 19 (1): 54-61.

Budiarsa AA, Rizal S. 2014. Community structure of macrozoobenthos in mangrove ecosystem, Kutai National Park, East Kalimantan. Intl J Sci Eng 7 (1): 91-94.

Cañizares LP, Seronay RA. 2016. Diversity and species composition of mangroves in Barangay Imelda, Dinagat Island, Philippines. AACL Bioflux 9 (3): 518-526.

Dahuri R. 1991. Dynamic interactions between regional development and Kutai National Park, East Kalimantan, Indonesia. Science and the management of protected areas: proceedings of an international conference held at Acadia University, Nova Scotia, Canada, 14-19 May 1991.

FAO [Food Agriculture Organization of United Nations]. 2007. The world's mangroves 1980-2005: a thematic study in the framework of the Global Forest Resources Assessment 2005. Food Agriculture Organization of United Nations, Rome

Garcia KB, Malabrigo JrPL, Geva na DT. 2014. Philippines' mangrove ecosystem: status, threats and conservation. In: Mangrove Ecosystems of Asia: Status, Challenges and Management Strategies. Springer. New York.

Ghufrona RR, Kusmana C, Rusdiana. 2015. Mangrove Forest Composition and Structure in Sebuku Island, South Kalimantan. J Trop Silvicult Sci 6 (1): 15-26.

Giesen W, Wulffraat S, Zieren M, Scholten L. 2006. Mangrove Guidebook for Southeast Asia. FAO, Rome and Wetlands International, Wageningen.

Giesen W, Wulffraat S.1998. Indonesian mangroves part I: Plant diversity and vegetation. Trop Biodiv 5 (2): 11-23.

Gunawan W, Sayektiningsih T. 2014. Restoration and Conservation of Mangrove Ecosystems in Kutai National Park. Wetland Conservation News, Wetlands International and DG PHKA, Ministry of Forestry, Jakarta.

Ifo SA, Moutsambote JM, Koubouana F, Yoka J, Ndzai SF, Orcellie LN, Kadilamio B, Mampouya H, Jourdain C, Bocko Y, Mantota AB, Bemba M, Mouanga-Sokath D, Odende R, Mondzali, LR, Wenina YEM, Ouissika BC, and Joel LJ. 2016. Tree species diversity, richness, and similarity in intact and degraded forest in the tropical rainforest of the Congo Basin: Case of the Forest of Likouala in the Republic of Congo. Intl J For Res 2016: 7593681. DOI: 10.1155/2016/7593681 1-12.

Juliana, WWA., Razali MS., Latiff, A. 2014. Distribution and rarity of Rhizophoraceae in peninsular Malaysia. Springer, New York.

Kartika KF, Istomo, Amanah, S. 2018. Mangrove Diversity in Production Forest Management Unit (FMU) Bulungan Unit VIII North Kalimantan. Media Konservasi 23 (3): 253-261.

Kathiresan K, Bingham BL. 2001. Biology of mangrove and mangrove ecosystems. Adv Mar Biol 40: 8151

Kordi K, Ghufran M.. 2012. Mangrove ecosystem: Potential, Function, Management. Rineka Cipta, Jakarta. [Indonesian]

Magurran AE. 1988. Ecology Diversity and Its Measurement. Princeton University Press, New Jersey.

Mann KH. 1982. Ecology of Coastal Waters: A System Approach. University of California Press, Berkeley, CA.

Mukhlisi W, Gunawan. 2016. Mangrove seed natural regeneration in degradation area of Kutai National Park Regeneration. Wallacea For Res J 5 (2): 113-122.

Noor YR, Khazali M, Suryadiputra INN. 2006. Mangrove introduction in Indonesia. Wetlands International and Ditjen PHKA, Bogor.

Primack RB. 1983. Forester's Guide to the Moraceae of Sarawak. Forest Department of Sarawak, Sarawak.

Rahmadani F, Ismawan MA, Syoim M. 2004. Mangrove in Kutai National Park Face: Mangrove Potential Survey Report in Kutani National Park, East Kalimantan. Yayasan BIKAL, Samarinda. [Indonesian] 
Rao P, Rao BP. 2017. Vegetation analysis of mangroves at Bhavanipuram, Kammavari cheruvu and Malakayalanka in Krishna district, Andhra Pradesh. Intl J Sci Res Educat 5 (6): 6540-6551.

Saenger P. 1999. Sustainable Management of Mangroves. Integrated coastal and marine resource management: Proceedings of International Symposium, Batu, Malang, Indonesia, 25-27 November 1999, National Institute of Technology (ITN) Malang in association with Bakosurtanal and Proyek Pesisir, Malang, Indonesia.

Sayektiningsih T, Gunawan W. 2012. Socio-economic conditions of the community around the mangrove forest of Kutai National Park, East Kalimantan. Proceedings of the seminar on the results of the research of BPTKSDA Samboja, Research Institute for Natural Resources Conservation, Samboja. [Indonesian]

Shah K, Kamal AHM, Rosli Z, Hakeem KR, and Hoque MM. 2016. Composition and diversity of plants in Sibuti mangrove forest, Sarawak, Malaysia. For Sci Technol 12 (2): 70-76.

Suwignyo RA, Dahlan Z, Munandar, Ridho MR. 2015. Primary Mangrove Forest Structure and Biodiversity. Intl J Agric Syst 3 (2): 135-141.
Thomas N, Lucas R, Bunting P, Hardy A, Rosenqvist A, Simard M. 2017. Distribution and drivers of global mangrove forest change. PLoS One 12 (6): e0179302. DOI: 10.6084/m9.figshare.4990982.v1.

Wan Juliana WA, Razali MS, Latiff A. 2014. Mangrove ecosystems of Asia: status, challenges and management strategies.

Widyastuti A, Yani E, Nasution EK, Rochmatino. 2018. Diversity of mangrove vegetation and carbon sink estimation of Segara Anakan Mangrove Forest, Cilacap, Central Java, Indonesia. Biodiversitas 19 (1) : 246-252

Wijaya NI. 2011. Management of Mangrove Ecosystem Utilization Zones through Optimization of Utilization of Mangrove Crab Resources (Scylla serrata) in Kutai National Park, East Kalimantan Province. [Dissertation]. School of Graduates, IPB University, Bogor. [Indonesian]

Zain Z, Hutabarat S, Prayitno B, dan Ambaryanto. 2014. Potency of Mahakam Delta in East Kalimantan, Indonesia. Intl J Sci Eng 6 (2): 126-130. 